\title{
Pattern of skin bacteria in palmar arsenical keratosis
}

\author{
Nadia Bintha Khalil', Mir Misbahuddin¹ and Abu Naser Ibne Sattar² \\ ${ }^{1}$ Division of Arsenic Research, Department of Pharmacology, Faculty of Basic Science and Paraclinical Science, \\ Bangabandhu Sheikh Mujib Medical University, Dhaka, Bangladesh; ${ }^{2}$ Department of Microbiology and Immunology, \\ Faculty of Basic Science and Paraclinical Science, Bangabandhu Sheikh Mujib Medical University, Dhaka, Bangladesh.
}

\begin{tabular}{|c|c|}
\hline \multicolumn{2}{|l|}{ Article Info } \\
\hline Received: & 26 November 2016 \\
\hline Accepted: & 10 December 2016 \\
\hline Available Online: & 16 December 2016 \\
\hline \multicolumn{2}{|c|}{ DOI: 10.3329/bjp.v11i4.30465 } \\
\hline \multicolumn{2}{|c|}{$\begin{array}{l}\text { Cite this article: } \\
\text { Khalil NB, Misbahuddin M, Sattar } \\
\text { ANI. Pattern of skin bacteria in pal- } \\
\text { mar arsenical keratosis. Bangladesh J } \\
\text { Pharmacol. 2016; 11: 940-943. }\end{array}$} \\
\hline
\end{tabular}

\begin{abstract}
The aim of the present study was to examine the involvement of skin bacteria in the pathogenesis of keratosis. Skin swab of five different sites (palm, dorsum of the hand, chest, axilla and alar crease) from arsenic unexposed volunteer $(n=15)$, arsenic exposed $(n=15)$ and arsenicosis patients $(n=20)$ were collected for bacterial culture. The skin of arsenic unexposed volunteers contained Staphylococcus epidermidis and Bacillus spp. Chronic exposure to high concentration of arsenic through drinking water altered the skin bacterial pattern. The growth of Pseudomonas spp. increased in different sites of the skin. But in patient of arsenicosis, the skin of the palm shows the growth of Enterobacter spp.
\end{abstract}

\section{Introduction}

Arsenicosis is a clinical condition that develops following chronic ingestion of high concentration of arsenic through drinking water (Misbahuddin, 2015). Its clinical feature usually manifested first in the skin as black pigmentation (melanosis), rain-drop appearance in the skin of chest and back (leucomelanosis), and presence of nodule/cauliflower growth in the palm and/or sole (keratosis) (Caussy, 2005). One peculiarity of keratosis is that single palm or sole is not affected. Once affected, both palms and/or soles are affected.

Water loss through skin mainly occurs by sweating. In addition, there is transepidermal water loss by diffusion. Compared with that of the back, the transepidermal water loss is four times greater on the forehead, nine times greater on the back of the hand, and one hundred times greater through the palm (Baker and Kligman, 1967). Therefore, large amount of arsenic is excreted through these two sites.

Human skin surface contains around 1 trillion bacteria which survive from the secretory product of skin. There are variations in the type of bacteria (around 1,000 species) in different areas of the skin (Grice et al., 2009). Specific bacteria being associated with moist, dry and sebaceous microenvironments (Grice and Segre, 2013).

The relationship between the bacterial pattern in palm/ sole and the keratosis is not known.

\section{Materials and Methods}

This study was conducted in an arsenic endemic area (Comilla District, about $110 \mathrm{~km}$ from Dhaka) from October 2014 to January 2016. List of palmar arsenical keratosis patients $(n=105)$ and their addresses were collected from the Upazilla Health Complex of Muradnagar, Comilla (Figure 1). Detailed history and clinical examination were taken. Photographs of both palms were taken by smart phone. The diagnosis was confirmed by the presence of arsenic in water and nail. Among the 37 patients of moderate arsenical keratosis, 20 were randomly included in this study. Arsenic unexposed healthy volunteers $(n=15)$ and arsenic exposed individuals $(n=15$; family member of the patient) were included for comparison. 


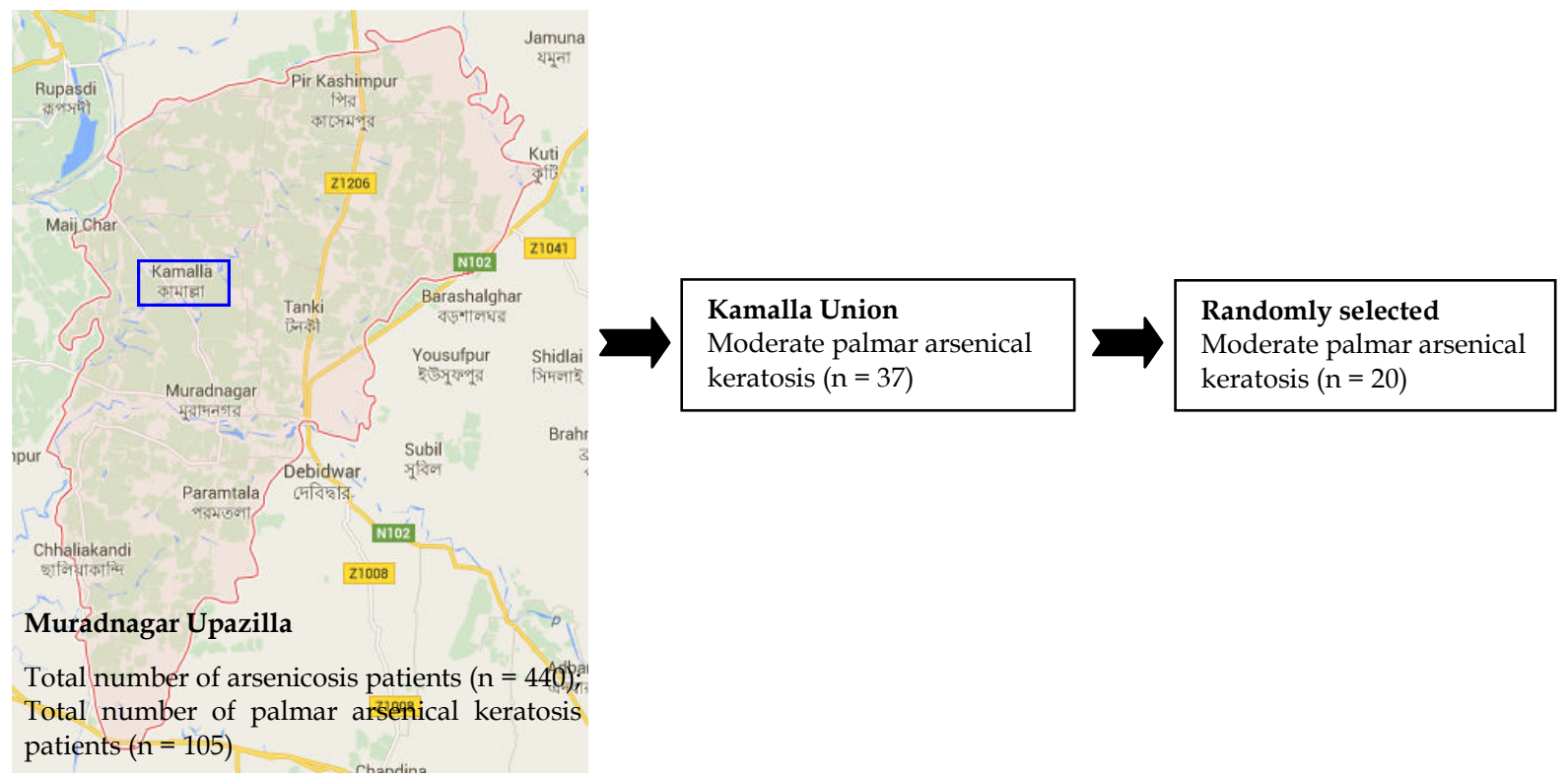

Figure 1: Selection of patients

Inclusion criteria are: a) age (18-60 years), b) sex (male and female), and c) subjects who voluntarily agreed to participate. Exclusion criteria are: a) age (below 18 or above 60 years), b) expectant/lactating mother, c) suffering from chronic diseases (tuberculosis, diabetes, hypertension, hepatitis, arthritis, systemic lupus erythromatosus), d) patient taking vitamin E/selenium, and e) suffering from other skin diseases (atopic dermatitis, psoriasis, eczema, etc).

The samples drinking water $(50 \mathrm{~mL})$ and nails (>200 $\mathrm{mg}$ ) were collected in separate containers to estimate the amount of total arsenic by SDDC method (Bhuiyan et al., 2015). One drop of concentrated hydrochloric acid was added to the container for drinker water as preservative.

Skin swabs were collected from the right palm of the hand for bacterial identification. Other four sites were included (dorsum of the hand, front of the chest, axilla and alar crease) as control. At first rubbed the selected areas eight times by a sterile swab stick separately, and then moistened with a solution of nutrient broth and Tween $80(10 \%)$. Swab stick was then placed in separate screw capped test tube containing $1 \mathrm{~mL}$ of the above mixed solution and finally brought to the Department of Microbiology and Immunology. On the next day, inoculation of bacteria was done on blood and chromogenic agar media and finally incubated at $35^{\circ} \mathrm{C}$ for 16-18 hours.

Bacteria were identified by observing the colony, Gram staining, microscopic examination and biochemical tests.

The study was approved by the University Institutional Review Board (Ref. No. 5102). All participants were informed about the nature and purpose of the study in local language (Bangla) and then written consent was taken from each participant.

\section{Results}

Staphylococcus epidermidis and Bacillus spp. were mainly found in the skin of healthy volunteers (Table I). There was no statistically significant difference in pattern of $S$. epidermidis, Bacillus spp. and Enterococci spp. between healthy volunteers, arsenic exposed volunteers and patients. When comparison was done between arsenic exposed volunteers and patients, there was a significant difference of Enterobacter spp. pattern in the palm of the hand.

There was statistically significant difference of Pseudomonas spp. pattern on skin of arsenic exposed volunteers and patients in comparison to healthy volunteers. Statistically significant changes were observed in the axilla and alar crease area of arsenic exposed volunteers and patients in comparison to healthy volunteers. In the dorsum of the hand, there was a significant change of $S$. aureus in patients in comparison to healthy volunteers.

\section{Discussion}

The present study shows that the normal human skin in an arsenic affected area contains Staphylococcus epidermidis and Bacillus spp. Chronic exposure to high concentration of arsenic through drinking water alters the skin bacterial pattern. The growth of Pseudomonas $s p p$. Increases in different sites of the skin. But in patient 
Table I

\section{Isolation of different bacteria from the five anatomical sites of skin}

\begin{tabular}{|c|c|c|c|c|}
\hline Area & $\begin{array}{l}\text { Arsenic unexposed } \\
\text { healthy volunteers } \\
\qquad(\mathrm{n}=15)\end{array}$ & $\begin{array}{l}\text { Arsenic exposed } \\
\text { volunteer } \\
(\mathrm{n}=15)\end{array}$ & $\begin{array}{l}\text { Arsenicosis } \\
\quad(\mathrm{n}=20)\end{array}$ & $\mathrm{p}$ value \\
\hline \multicolumn{5}{|c|}{ Staphylococcus epidermidis } \\
\hline Palm & 11 & 7 & 14 & \\
\hline Dorsum & 10 & 8 & 17 & \\
\hline Chest & 10 & 8 & 13 & \\
\hline Axilla & 10 & 10 & 18 & \\
\hline Alar crease & 9 & 9 & 17 & \\
\hline \multicolumn{5}{|l|}{ Bacillus spp. } \\
\hline Palm & 9 & 7 & 7 & \\
\hline Dorsum & 8 & 5 & 14 & \\
\hline Chest & 8 & 6 & 10 & \\
\hline Axilla & 6 & 7 & 8 & \\
\hline Alar crease & 7 & 8 & 7 & \\
\hline \multicolumn{5}{|c|}{ Staphylococcus aureus } \\
\hline Palm & 4 & 4 & 5 & \\
\hline Dorsum & 2 & 5 & 10 & $0.04 \&$ \\
\hline Chest & 2 & 4 & 9 & \\
\hline Axilla & 1 & 4 & 5 & \\
\hline Alar crease & 1 & 5 & 4 & \\
\hline \multicolumn{5}{|l|}{ Enterococci spp. } \\
\hline Palm & 3 & 0 & 5 & \\
\hline Dorsum & 3 & 1 & 5 & \\
\hline Chest & 3 & 4 & 2 & \\
\hline Axilla & 1 & 1 & 1 & \\
\hline Alar crease & 3 & 0 & 2 & \\
\hline \multicolumn{5}{|l|}{ Enterobacter spp. } \\
\hline Palm & 2 & 0 & 7 & $0.029^{*}$ \\
\hline Dorsum & 2 & 5 & 8 & \\
\hline Chest & 5 & 2 & 7 & \\
\hline Axilla & 6 & 1 & 7 & \\
\hline Alar crease & 1 & 1 & 5 & \\
\hline \multicolumn{5}{|c|}{ Pseudomonas spp. } \\
\hline Palm & 1 & 10 & 13 & $0.015 \dagger, 0.003 \&$ \\
\hline Dorsum & 1 & 8 & 20 & $0.045 \dagger, 0.001 \&$ \\
\hline Chest & 1 & 12 & 16 & $0.005 \dagger, 0.001 \&$ \\
\hline Axilla & 2 & 10 & 15 & $0.043^{\dagger}, 0.009 \&$ \\
\hline Alar crease & 0 & 9 & 10 & $0.007 \dagger, 0.004 \&$ \\
\hline \multicolumn{5}{|l|}{ Escherichia coli } \\
\hline Palm & 2 & 7 & 9 & \\
\hline Dorsum & 2 & 7 & 2 & \\
\hline Chest & 4 & 11 & 5 & \\
\hline Axilla & 3 & 13 & 10 & $0.038+; 0.043^{*}$ \\
\hline Alar crease & 0 & 7 & 4 & $0.023+$ \\
\hline
\end{tabular}

Samples were collected from the right palm, right dorsum of the hand, right axilla and right alar crease and front of the chest; McNemar's test was done for statistical analysis. tarsenic unexposed vs arsenic exposed; *arsenic exposed vs arsenicosis; \&arsenic unexposed vs arsenicosis 
of arsenicosis, the skin of the palm shows the growth of Enterobacter spp.

The most common is the Staphylococcus epidermidis which is occasionally pathogenic. The highest incidence of $S$. aureus is present in the groin and toe web (Aly and Maibach, 1977). Diphtheroids (lipophilic and nonlipophilic), together with coagulase-negative staphylococci and micrococci, are the dominant aerobic and facultative residents of the normal skin flora (Kligman, 1965).

One study shows that total microbial count was higher in arsenicosis (forearm $>$ finger web $>$ upper chest) than the control (Jyoti et al., 2011). E. coli and Pseudomonas spp. are the most predominant candidates. Other candidates like Acinetobacter spp., Moraxella spp., Klebsiella spp. and Neisseria spp. are found in arsenicosis patients.

Our focus is on the palm of arsenicosis. It is the site where keratosis develops in addition to sole (Caussy, 2005). Our data shows that Enterobacter spp is significantly present within it. As the patient of arsenicosis is exposed to high concentration of arsenic and its metabolites which might be involved in the growth of Enterobacter spp. But the growth of Enterobacter spp is not significantly increased in individual with arsenic exposure. We can predict that cauliflower growth may enhance the growth of Enterobacter spp in the palm.

It is apparent that chronic arsenic exposure increases the growth of Pseudomonas spp in all the five sites of skin examined. That is, arsenic and its metabolites create a good environment in the skin of arsenic exposed individual and patient for the growth of Pseudomonas spp.

\section{Conclusion}

Arsenic exposure increases the growth of Pseudomonas spp. in the skin surface whereas the palm of arsenical keratosis shows, in addition, the presence of Enterobacter spp.

\section{References}

Aly R, Maibach HI. Aerobic microbial flora of intertrigenous skin. Appl Environ Microbil. 1977; 33: 97-100.

Baker H, Kligman AM. Measurement of transepidermal water loss by electrical hygrometry: Instrumentation and responses to physical and chemical insults. Arch Dermatol. 1967; 96: 441-52.

Bhuiyan HA, Tshering K, Misbahuddin M. Estimation of arsenic in nail using silver diethyldithiocarbamate method. Bangladesh J Pharmacol. 2015; 10: 513-17.

Caussy D. A field guide for detection, management and surveillance of arsenicosis cases. New Delhi, WHO Regional Office for South-East Asia, 2005.

Grice EA, Kong HH, Conlan S, et al. Topographical and temporal diversity of the human skin microbiome. Science 2009; 324: 1190-92.

Grice EZ, Segre JA. The skin microbiome. Nat Rev Microbiol. 2011; 9: 244-53.

Jyoti A, Bonny TS, Hossain MA. Arsenic poisoning alters the composition of skin microbial flora of human. Res J Microbiol. 2011; 6: 524-33.

Kligman AM. The bacteriology of normal skin. In: Skin bacteria and their role. Maibach HI, Hildick-Smith G (ed.). New York, McGraw-Hill, 1965, pp 13-31.

Misbahuddin M. Arsenicosis: A global issue. New York, Science Publishing Group, 2015, pp 1-204.

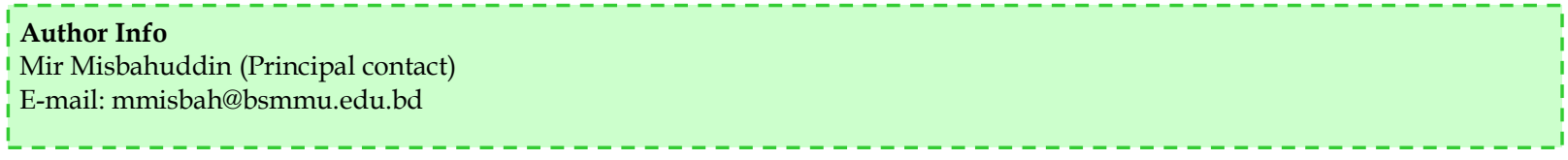




\section{Your feedback about this paper}

1. Number of times you have read this paper 0

2. Number of times you have seen the video clip 0

3. Quality of paper Click

4. Your comments

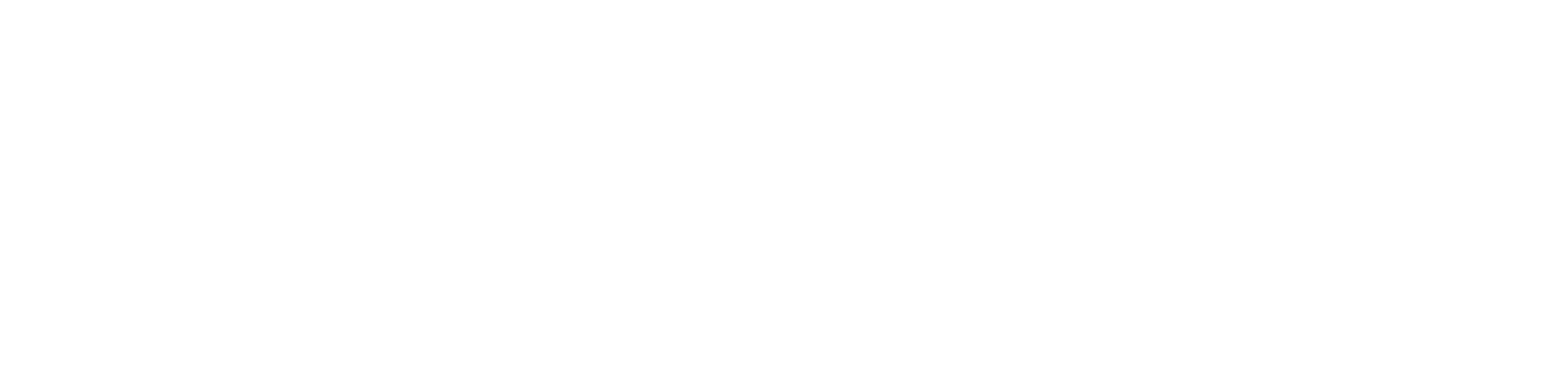

